\title{
THE MLADOTICE LAKE, WESTERN CZECHIA: THE UNIQUE GENESIS AND EVOLUTION OF THE LAKE BASIN
}

\begin{abstract}
JANSKÝ, B., SCHULTE, A., ČESÁK, J., RIOS ESCOBAR, V. (2010): The Mladotice Lake, western Czechia: The unique genesis and evolution of the lake basin. Geografie, 115, No. 3, pp. 247-265. - The Mladotice Lake is a lake of unique genetic type in Czechia. In May 1872 a landslide as a result an extreme rainfall event occurred in western Czechia, blocking the Mladotický stream valley and creating the Mladotice Lake. The 1952 and 1975 air images document that collective farming had a great impact on the lake basin evolution when balks and field terraces were removed and fields were made much larger. Because of this change in land use we expected higher soil erosion and a related increase in the sedimentation rate. First bathymetric measurements of the newly created lake were carried out in 1972 and were repeated in 1999 and in 2003. Our analysis of the sedimentary record aims to identify the sediment stratigraphy, its basic physical and chemical properties, isotope content and thin sections yield a detailed temporal resolution of the sedimentation chronology. In some areas a sediment thickness of $4 \mathrm{~m}$ was detected. Hence, the average sedimentation rate is from 2.2 to $2.7 \mathrm{~cm}$ per year.
\end{abstract}

KEY WORDS: Mladotice Lake - extreme rainfall event - landslide - land use changes flood events - bathymetric measurements - sedimentation dynamics - stratigraphy and geochemistry of lake sediments - analyses of isotopes - sedimentation rates.

This research was funded by the Czech Ministry of Education Project "Geographical Systems and Risk Processes in the Context of Global Change and European Integration" (MSM 0021620831), and Czech Ministry of Agriculture Project "Water Retention in the River Flood - Plain Areas" (QH82078).

\section{Introduction}

During the final days of May 1872, an extensive area of south-western and western Bohemia were afflicted by a massive incident of torrential rain, which according to historical reports lasted from noontime on 25 May until the morning of the following day. The Plzen rain-gauge station recorded two thunderstorms on 25 May 1872, from which a total of $40 \mathrm{~mm}$ of precipitation were measured (Skrejšovský 1872). However, a far greater total of precipitation fell north of Plzeň, where at that time there was no precipitation measuring station in operation. Nevertheless, Karel Kořistka, a prominent cartographer at the time, provided a detailed description of the meteorological situation (Kořistka 1872): "Observed in Mladotice, a standing empty vessel that was 9 inches, or $237 \mathrm{~mm}$, tall was filled to the brim within one hour's time to the point that additional rain overflowed the vessel..." This report of $237 \mathrm{~mm}$ of 


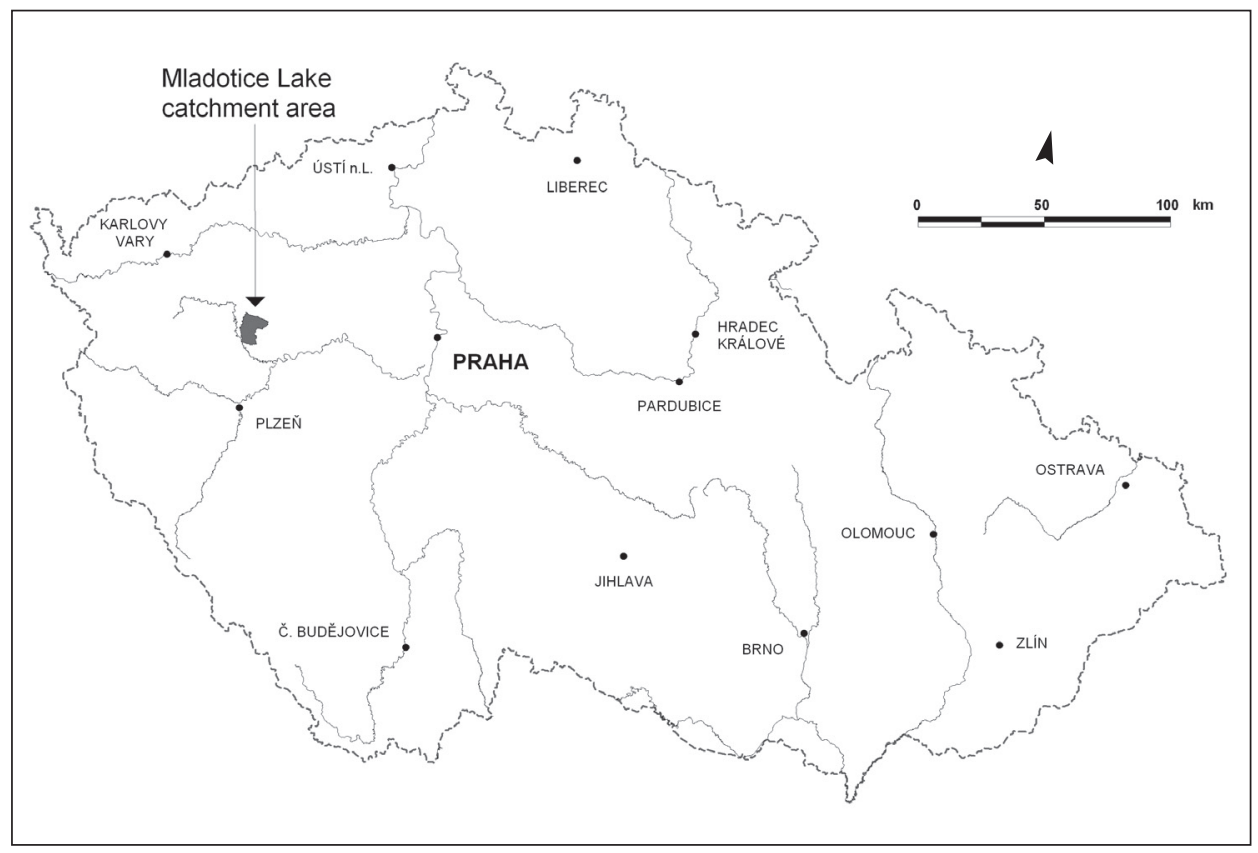

Fig. 1 - Drainage basin of the Mladotice Lake and the study area in western Czechia

precipitation in one hour was long time considered to be unrealistic. Only with a measurement of torrential rain in southern Slovakia, i.e. in a similar Central European climate zone, recorded on 12 June 1957, when $225.5 \mathrm{~mm}$ of precipitation fell during 65 minutes at Skalka by Štúrovo (southern Slovakia), was the feasibility of these earlier data confirmed (see Štekl et al. 2001). The extreme precipitation caused an extraordinarily destructive flood which devastated the catchment areas of the Střela and Blšanka Rivers as well as most of the Berounka River basin below Plzeň. On 26 May at 14:00, the discharge of the Vltava in Prague was measured at $3300 \mathrm{~m}^{3} / \mathrm{s}$, which represents the fifth largest flood observed since 1825 (Brázdil et al. 2005).

In connection with the extraordinary intensity of precipitation, two natural catastrophes occurred in the valley of the Mladotický stream (the left tributary of the Střela River, Fig. 1). During the night from 27 to 28 May, large masses of arkose and conglomerate from the western slope of the Potvorovský Hill (546 m) slid down into the Mladotický stream's valley, damming the stream with a massive dike (Figures 4 and 5). The resulting lake is, to this day, the only example of such a genetic type of lake in the Bohemian Massif. The second disastrous event was the rupture of the Mladotický Fishpond dam, which was located at the southern edge of Mladotice Municipality. With an area of roughly 92 ha it was, at that time, the largest fishpond in western Bohemia. After its destruction, the pond was never restored (see the map in Fig. 2).

Geoscientists increasingly aim to distinguish between landscape changes due to natural processes and those caused or triggered by human activity (Barsch et al. 1993; Janský, Urbanová 1994; Favis-Mortlock et al. 1997; Bork et al. 1998; Völkel 2005; Bičík, Kabrda 2007; Bičík, Jeleček 2009). 


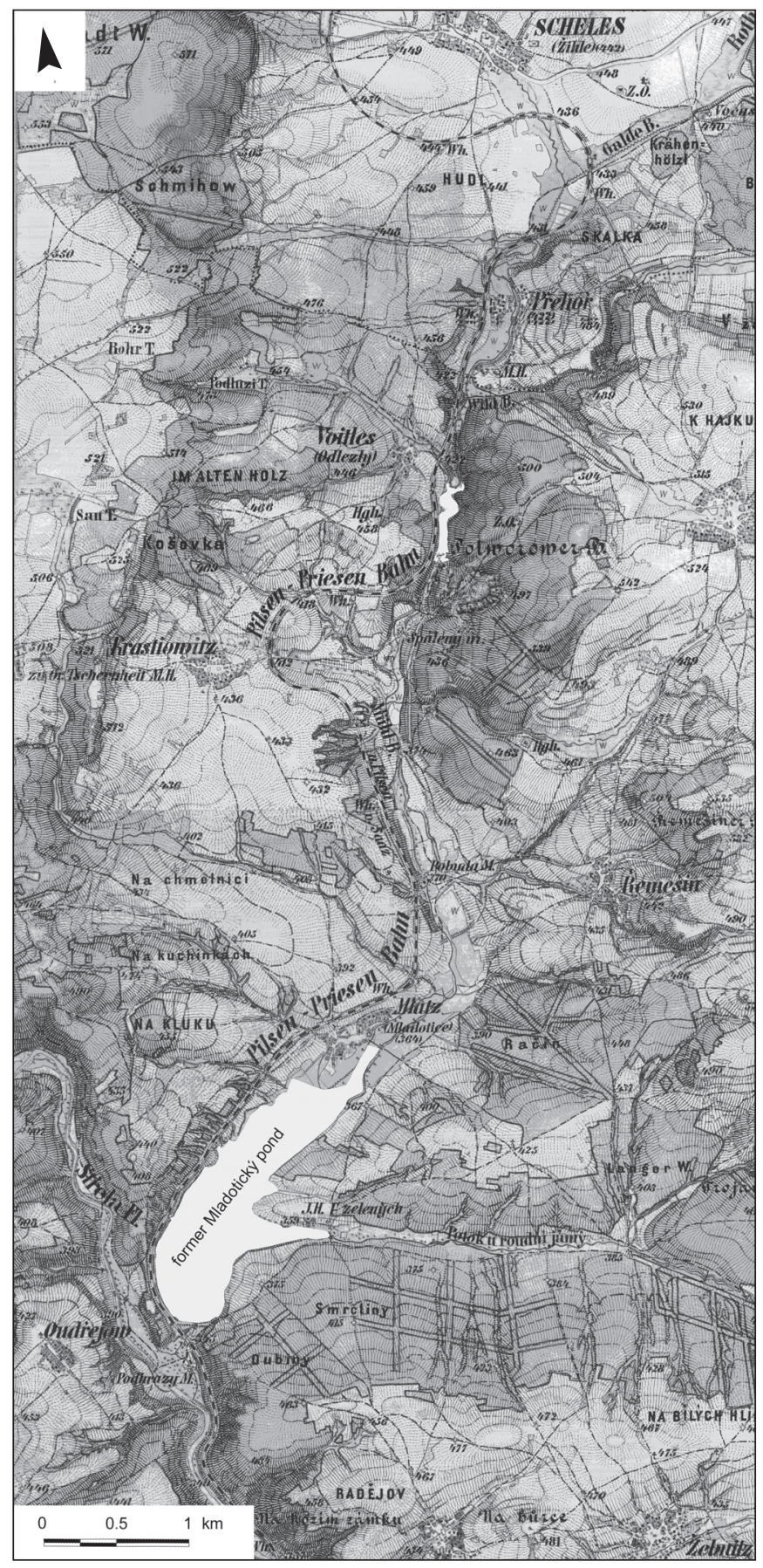

Fig. 2 - The map of the Third Military Mapping of Austrian Monarchy from 1890. The map illustrates the newly originated Mladotice Lake and the former Mladotický Fishpond, which was located at the southern edge of Mladotice Municipality. 
The latter include very different processes at different scales in time and space, starting with human impact on the landscape balance since the Neolithic (e.g. Andres 1998, Kalis et al. 2003). The older the geoarchives, the more difficult and blurred are interpretations of their controlling factors. For instance, higher sedimentation rates in the Hegau region (west of Lake Constance) during the Bronze Age may be due to larger areas under cultivation, changing land use practices and/or more intensive or increased rainfall/runoff processes. The historical geoarchives sometimes do not reveal which of these factors ultimately caused greater soil erosion (Schulte, Heckmann 2002).

Improved dating techniques are necessary to increase the temporal resolution of the sediment records which have clearly increased the level of knowledge in recent years (e.g. Kadereit et al. 2002, Lang 2003, Zolitschka et al. 2003, Geyh 2005, Schulte et al. 2006, Kadlec et al. 2009).

When examining sediment archives from recent times we may have the opportunity to identify the factors controlling sediment formation in much more detail (e.g. Junge et al. 2005). This was the case with the natural „experimental setup" at the Mladotice Lake (western Czechia), where we were able to analyse a sediment archive dating back to 1872 . Since the onset of lake sedimentation, rainfall and runoff have been recorded (in some cases continuously) at monitoring stations which are located in the surrounding area, within the catchment area of the lake. Air images from 1938 to 1998 document land use changes in the lake's drainage basin.

Because of the change in land use we expect higher soil erosion and a related increase in the sedimentation rate with greatest impact between 1952 and 1975. Against this background, our investigations into the lake sediments and the drainage area of the Mladotice Lake aim to address the following questions:

- What were the primary causes behind the lake's formation?

- How deep was the lake, directly after its formation?

- To what extent has land use changed in the drainage basin of the Mladotice Lake since 1872 ?

- Have the magnitude or frequency of the rainfall/runoff events changed since $1872 ?$

- To what extent is the sediment record a product of rainfall/runoff events or the change in land use in the drainage basin?

\section{Landslide factors and lake creation}

The Mladotice Lake is located in western Czechia about $30 \mathrm{~km}$ north of Plzen̆ (Fig. 1). Its altitude is $413 \mathrm{~m}$ above sea level and its surface area is 4.74 ha. The lake receives drainage from a basin of approx. $30 \mathrm{~km}^{2}$, about $50 \%$ of which is intensively farmed. The lake's drainage basin - including the type of land use - is typical for a large region of western Bohemia. The bedrock mainly consists of Paleozoic shale, sandstone and conglomerate, with some Proterozoic phyllite and spilite and Paleozoic granite (Český geologický ústav 1996).

The lake basin is formed by a narrow valley of the Mladotický stream at the west side of the Potvorovský Hill. Its receiving streams are the Střela and Berounka Rivers; the latter flows into the Vltava River south of Prague. 
The conditions for a landslide to occur on the slopes of the Potvorovský Hill originated long before the catastrophic landslide of 1872. It is clear that there was no one single factor that caused the slide. There were multiple causes and these should be viewed in light of their mutual connections and not as isolated factors, due to the fact that each of them contributed to a certain degree to disrupting the stability of the slope (Janský 1976, 1977):

1. The Mladotický stream flows in an approximately north-south direction. The main tectonic faults are oriented in the same direction. It is likely that stream's valley is tectonically predisposed. In such a case, deepening erosion, wherein the stream cut deeper and deeper into layers of Carboniferous arkose, sandstone and conglomerate, could have progressed more rapidly. After cutting through this set of rocks, the stream reached layers of soft shale sediments. These layers became saturated with water and minor slip surfaces probably emerged at the foot of the slope. However, the water also managed to reach these underlying clay minerals through numerous fissures in the upper sections of the slope. Due to the fact that the rock mass had already been disrupted, entire formations of carbonic minerals slid down into the valley (Heiland 1998). With the movement of the lower portion of the slope the existing fissures became large cracks, creating the conditions necessary for the movement of additional, progressively larger sections of the hillside. The movement was initially very slow, exhibiting the characteristics of downhill creep. This creeping movement was likely occurring throughout the area of the defined landslide territory (landslides I, II and III). It was only in the landslide I area, however, that a further landslide occurred in 1872 (Janský 1976), which proved to be catastrophic in nature (Fig. 3).

2 . The second factor behind the occurrence of the landslide was an anthropogenic impact. This concerns a number of old quarries, which to this day remain quite noticeable. A series of historical evidence confirms the quarrying of sandstone in the area of the Potvorovský Hill. For example, the Romanesque Church of St. Nicholas in Potvorov is constructed of large hewn stones, which came from the Potvorovský Hill (the church's construction dates back to approximately A.D. 1240). The quarrying of stone is also men-

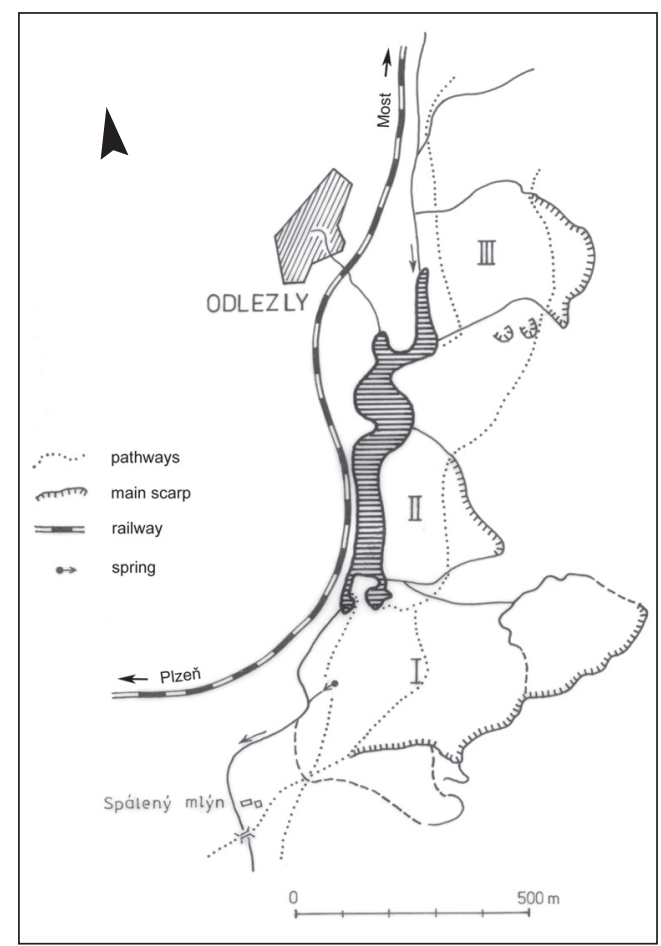

Fig. 3 - Comprehensive map of landslide areas on the western slope of the Potvorovský Hill. I - landslide area as of 1872, II, III - older landslide areas. 
tioned in the Kaceřov Urbarium (Kaceřovský urbář, a local, feudal record) from 1558 in a description of the Potvorov Municipality: "Near this village, there is a rocky mountain, from which millstones are quarried and the quarry workers are paid six grosh for each millstone quarried ..." Hewn blocks of sandstone from the Potvorovský Hill were transported to Plasy to be used in the construction of a Cistercian convent. J. A. Dunder (in Janský 1975) also writes about two quarries near Potvorov in 1845: "A quarter of an hour to the northwest of the place (Potvorov - author's note), there are two quarries for millstones, one of which belongs to the Rabštejn estate." Therefore, over the course of a few centuries, quarry activities contributed to the decreased stability of the slope. In addition, as part of this quarrying work, the topsoil and upper layers were disturbed, providing easier access for water from precipitation to reach the sub-layer locations of the clay minerals.

3 . The third agent, which to a certain degree contributed to the decreased stability of the slope, was the excavation work, conducted in 1872, for a railway track that cut through the west side of the Potvorovský Hill for a distance of roughly $200 \mathrm{~m}$. The track from Plzeň to Žatec was under construction at the time and was expected to open within the same year.

4. The intense rainfall at the end of May 1872 played a decisive role in the final phase of the landslide. The slope had already been sufficiently disrupted with numerous fissures, cracks, quarries and even the cutting of a railway track. The water easily penetrated the disrupted upper layers and proceeded to thoroughly saturate the coarse-grained and porous arkose, sandstone and conglomerate. This substantially increased the weight of the upper layers and even altered other physical characteristics of the mass of sandstone minerals (its rigidity and the tension of the minerals). After being saturated with water, the clay cement softened and the shale in the bedrock also became wet. Friction was reduced and masses of upper-layer minerals began to slide down into the stream valley. This movement took place over the space of two days, 27 and 28 May 1872. The landslide dammed the valley for a length of $300 \mathrm{~m}$ (Figs. 4 and 5).

\section{Methods}

Geodetic and bathymetric measurements of the Mladotice Lake were made in 1972, 1990 (Janský 1976, 1977; Janský, Urbanová 1994) and 2003 (Česák, Šobr 2005). By comparing the results of these measurements it is possible to analyse the dynamics of the lake's sedimentation in the past and to attempt to predict the further development of the lake basin, in other words to determine a period, after which the lake will be entirely filled with sediment (see maps in Fig. 6).

To reconstruct land use shifts the Military Topographical Institute in Dobruška supplied air photos taken in 1938, 1952, 1975, 1987 and 1998. Up to now only 2-D interpretation is possible, because of the lack of overlap. The air photos document a considerable land use change with the introduction of collectivization (Fig. 7). We anticipate that stereoscopic 3-D-interpretation of the air photos will show the removal of field terraces that accompanied field enlargement and also contributed to increased erosion (Janský 1976, 1977; Janský, Urbanová 1994). 


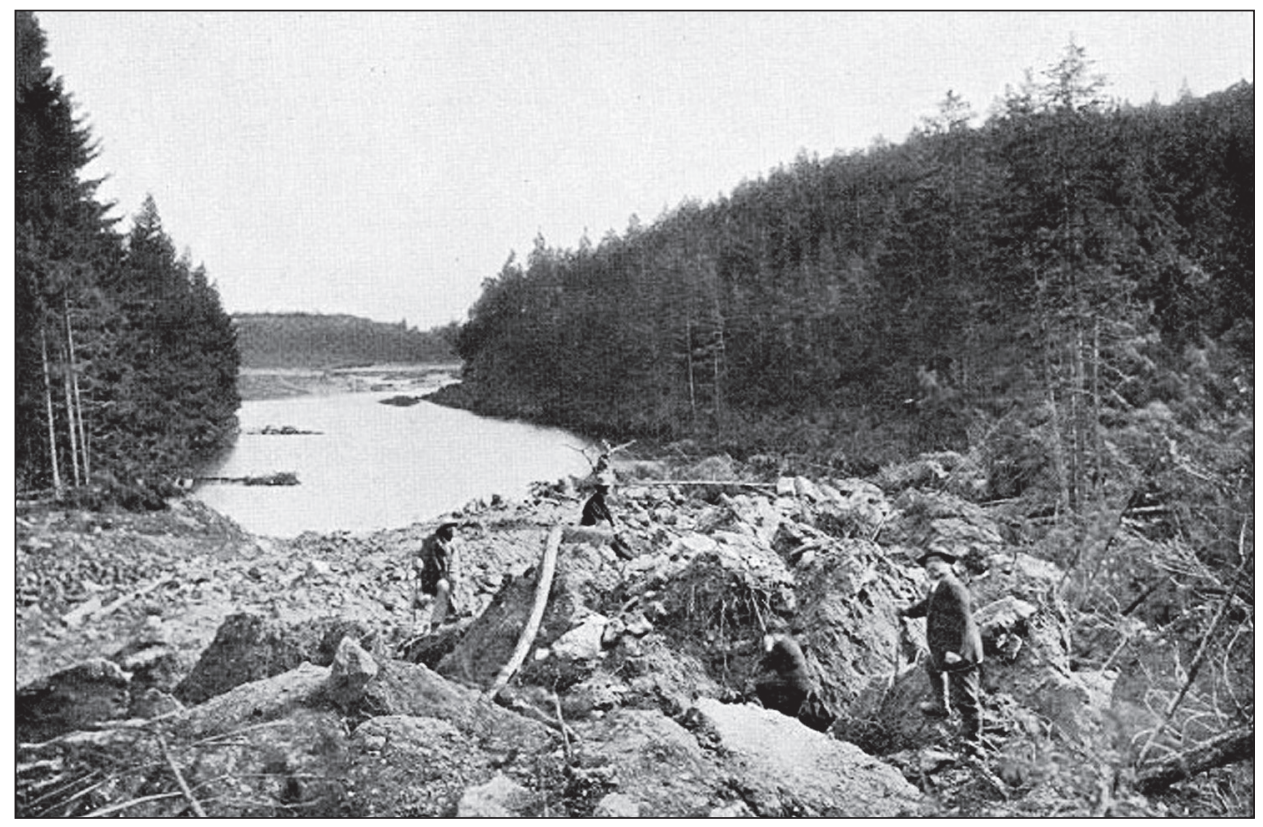

Fig. 4 - Dammed valley immediately after the landslide in May 1872, the lake is emerging in the background. Print from the Geografie (Sborník ČSZ) 28, Praha 1912. Photo by C. Purkyně.

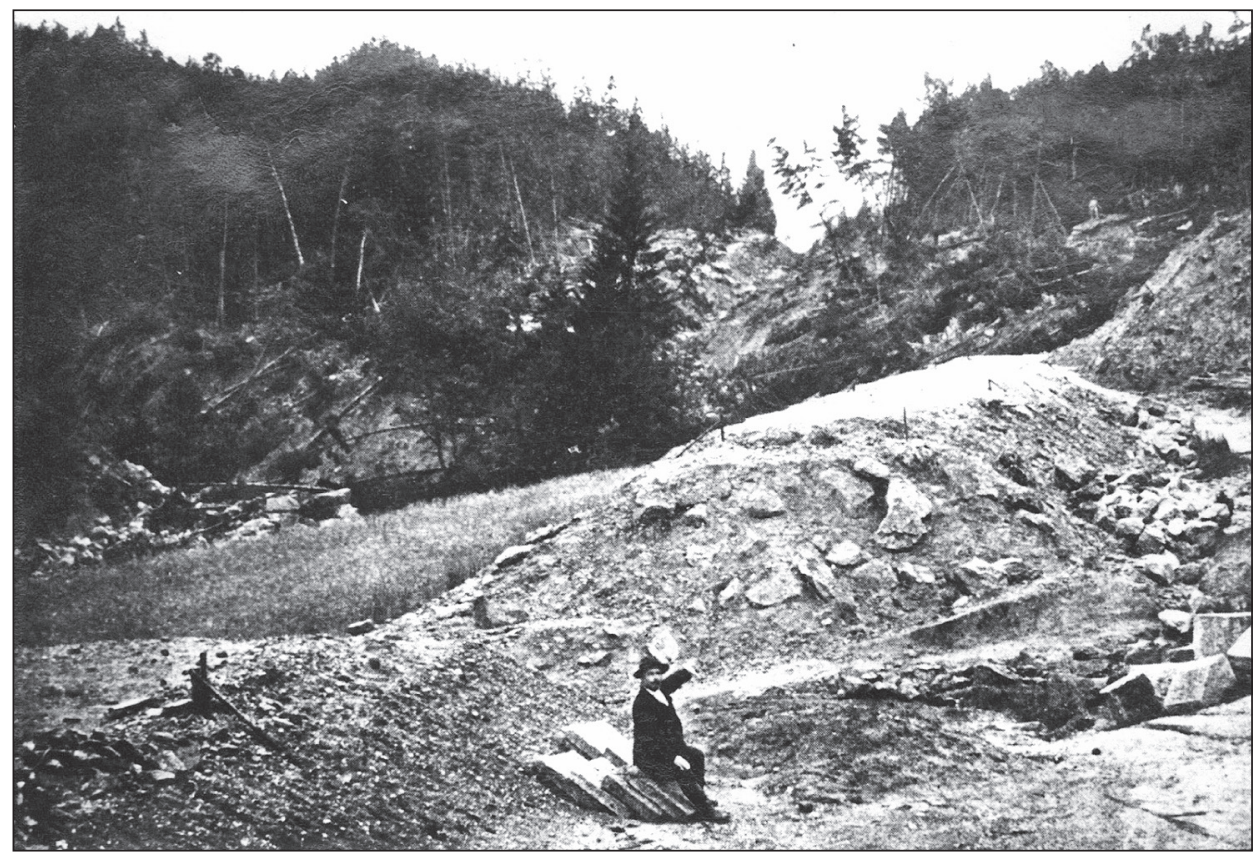

Fig. 5 - The bank of railway-track after the landslide in May 1872. Print from the Geografie (Sborník ČSZ) 28, Praha 1912. Photo by C. Purkyně. 


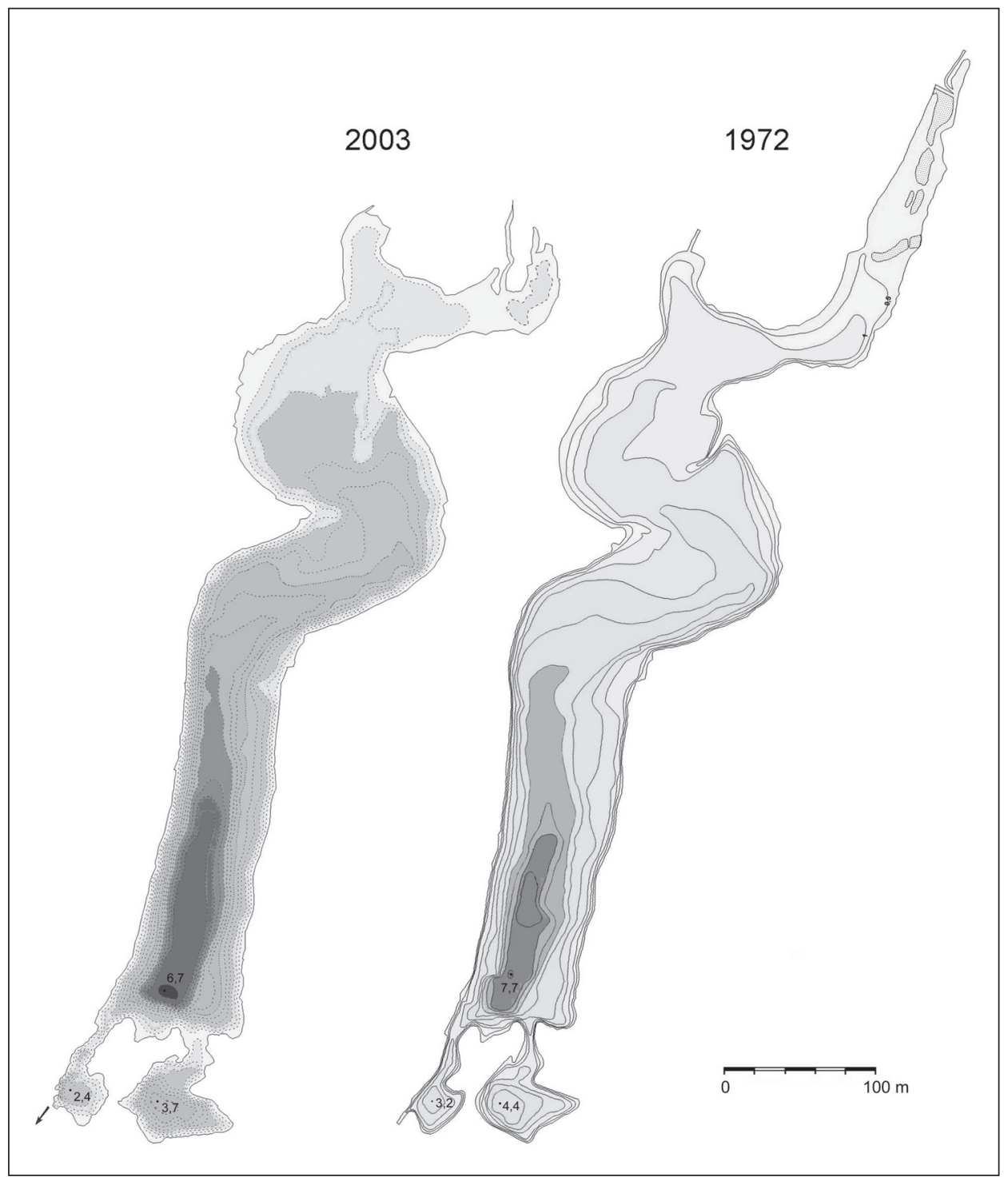

Fig. 6 - The bathymetric maps of the Mladotice Lake from measurements in 1972 and 2003

To assess the influence of natural factors on erosion, transport and sedimentation rates in the Mladotice Lake, rainfall data were analysed from six stations observing since 1881. The Kralovice, Plasy, Mladotice, Manětín, Liblín and Valečín stations are not located in the drainage area of the Mladotice Lake but they are the nearest stations in the surrounding area (in the distance between 5 and $20 \mathrm{~km}$ from the Mladotice Lake). The records of the above mentioned rain-gauge stations are not homogeneous and need to be examined carefully to identify the rainfall events relevant to flooding. Rainfall/runoff analyses should therefore focus on major events which covered the whole area 


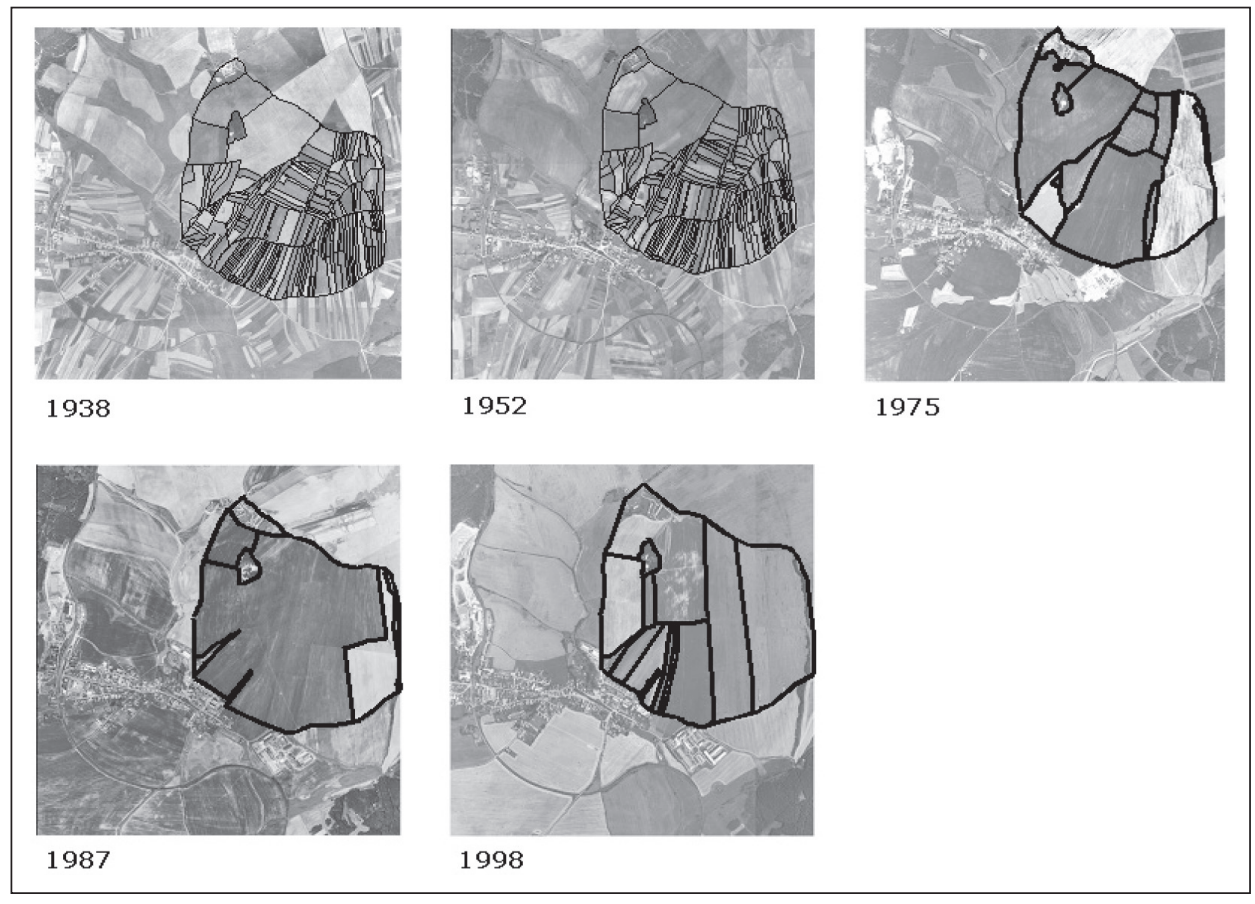

Fig. 7 - Air photos of a field about $1 \mathrm{~km}^{2}$ in size, northeast of the town of Žihle in the catchment area of the Mladotice Lake. Collective farming had the greatest impact in land use changes between 1952 and 1975. Photographs: Military Topographic Institute Dobruška.

represented by raing-gauge stations, including the drainage basin of the Mladotice Lake.

Runoff data serve to indicate the dimensions of past flood events. The nearest water-gauge station is located on the Střela River (Plasy station, $775 \mathrm{~km}^{2}$ ), which also drains the Mladotický stream. Daily records at this gauge date back to 1941. It is assumed that large floods recorded at the Střela River were also experienced at the Mladotický stream and that sediments were deposited in the lake during these events (Fig. 8).

To classify current sedimentation conditions and sediment properties we measured the oxygen content, conductivity, temperature, visible depth and stream flow of the lake water in the summers of 2003 and 2004 in a depth grid across the lake.

Sediment echography was used to measure sediment distribution along profiles in the lake basin in order to find suitable sites for core drilling. Unfortunately the sediments were extremely reflection-poor, and results were unsatisfactory. When the cores were analysed we found that the sediments were too gas-rich for using this method successfully.

In spite of this setback, we obtained information about the distribution of the sediments by extracting 13 short cores of about $1 \mathrm{~m}$ in length. Five long cores were drilled down to the bottom of the sediments. The reference core ML 18/03 was extracted from the deepest part of the lake and core ML 14/03 was investigated for diatom analyses. Core sites are shown in Figure 9. 


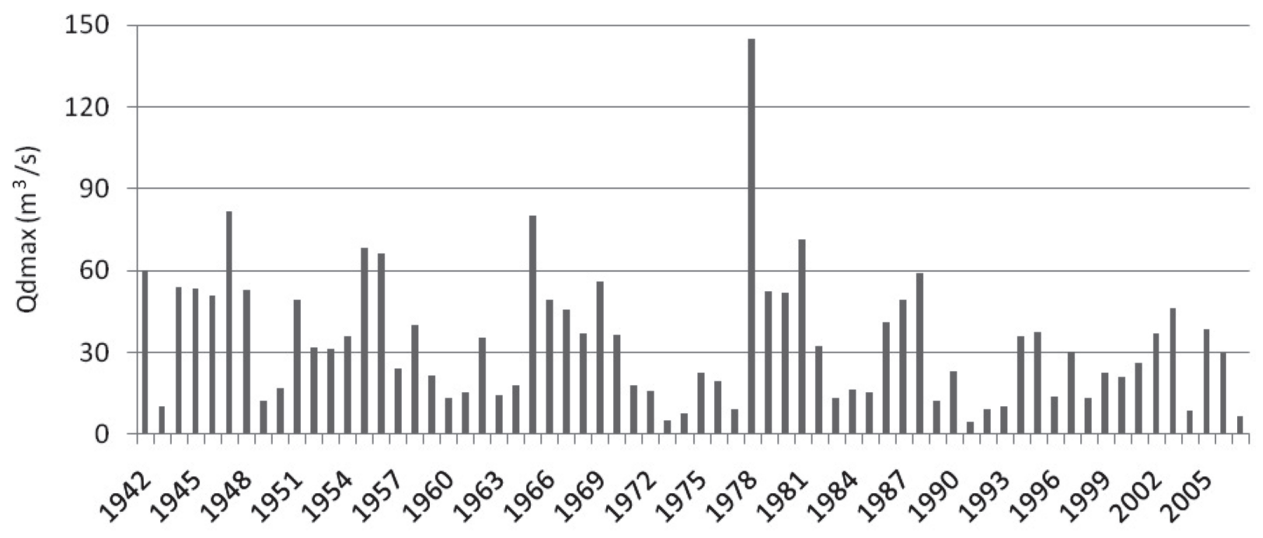

Fig. 8 - Maximum daily discharges in the Plasy (Střela River) station, the period of 1942-2007. Axis x - years. Sources: Czech Hydrometeorological Institute, Čuřík 2009.

Reference core ML 18/03 comprises analyses of water content, density, grain size, total sulphur, total carbon, total phosphorus, clay mineral composition, ${ }^{137} \mathrm{Cs},{ }^{241} \mathrm{Am}$ and ${ }^{210} \mathrm{~Pb}$ as well as thin sections from the entire length of the core. Sediment samples were taken and analysed every $10 \mathrm{~cm}$. It means that by long cores to the bottom of the sediments (with depth about $400 \mathrm{~cm}$ ) were investigated 40 samples. The upper part of the sediment core ML 14/03 was investigated for diatoms $(0-160 \mathrm{~cm}$ core depth). As agrochemicals can indicate system changes, we analysed their input into the lake. Fractionated organic analyses were conducted on four samples with GC-MS technology.

\section{Results}

\subsection{B athymetric $\mathrm{m}$ e a surements}

From the comparative analysis of bathymetric measurements from 1972 and 2003, the following results were gathered (Janský 2003): The maximum depth of the lake decreased from $7.7 \mathrm{~m}$ to $6.7 \mathrm{~m}$. The $7 \mathrm{~m}$ depth level entirely disappeared and

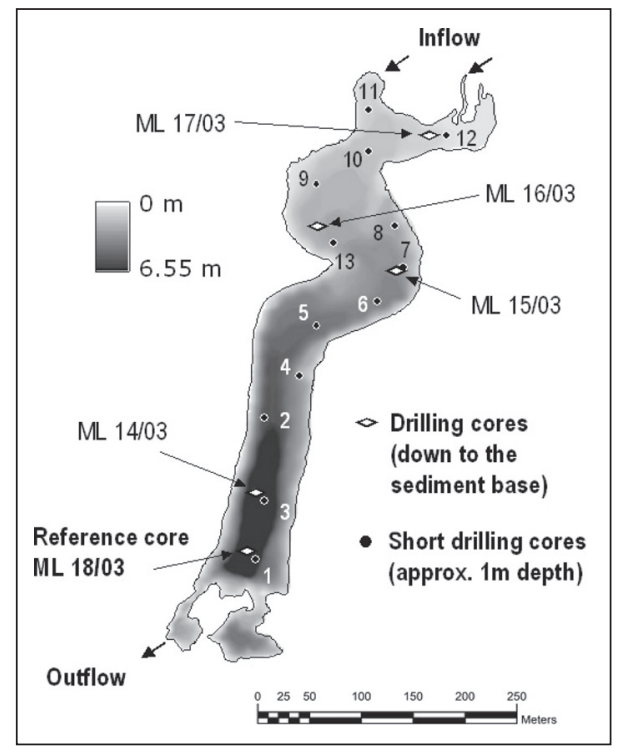

Fig. 9 - Map of the Mladotice Lake showing locations of short and long cores. The core ML 18/03 is located near the outflow with the maximum water depth. the area of all other depth levels decreased - the $6 \mathrm{~m}$ depth level decreased to $61 \%$ of its initial area from 1972, the $5 \mathrm{~m}$ level to $43 \%$, the $4 \mathrm{~m}$ level to $60 \%$ (see Table 1). The decline in the area of shallow water levels was somewhat less dramatic - the $3 \mathrm{~m}$ level decreased 
Tab. 1 - The results of bathymetric measurements in 1972 and 2003

\begin{tabular}{|l|c|c|c|c|}
\hline Year & \multicolumn{2}{|c|}{1972} & \multicolumn{2}{c|}{2003} \\
\hline Depth $(\mathrm{m})$ & Area $\left(\mathrm{m}^{2}\right)$ & Volume $\left(\mathrm{m}^{3}\right)$ & Area $\left(\mathrm{m}^{2}\right)$ & Volume $\left(\mathrm{m}^{3}\right)$ \\
\hline 0 & 58,562 & 141,380 & 47,364 & 103,910 \\
1 & 44,208 & 91,260 & 33,773 & 63,989 \\
2 & 31,690 & 56,880 & 21,853 & 36,181 \\
3 & 18,210 & 33,600 & 13,185 & 18,615 \\
4 & 12,008 & 18,140 & 7,154 & 8,739 \\
5 & 8,494 & 8,360 & 3,667 & 3,503 \\
6 & 3,364 & 2,840 & 2,052 & 602 \\
7 & 2,138 & 420 & 0 & 0 \\
7.7 & 0 & 0 & 0 & 0 \\
\hline
\end{tabular}

to $72 \%$ of its 1972 area, while the $2 \mathrm{~m}$ and $1 \mathrm{~m}$ levels decreased to $69 \%$ and $76 \%$, respectively. A decrease in water level's surface area was measured, i.e. from an initial 5.8562 ha (1972) to 4.7364 ha (2003). This means a decrease of 1.1198 ha in the lake's surface area, i.e. 19\% of its initial area in 1972. Maximum water level fluctuation between 1972 and 2009 was registered around 55 $\mathrm{cm}$. Moreover, the automatic water-gauge station has measured the fluctuation of $26 \mathrm{~cm}$ in the last 12 months. After eliciting the bathymetric curves, the volume of the lake basin was calculated. From an initial volume of $141,380 \mathrm{~m}^{3}$ (1972) it decreased to $103,910 \mathrm{~m}^{3}$, i.e. by $37,471 \mathrm{~m}^{3}$. Therefore, the lake basin volume decreased by $26.5 \%$.

\subsection{Changes in land use}

This paper describes the fundamental changes in the sediment dynamics. This also involves the details of bedding phenomena, grading and lamination of the sediments. Landscape changes in the drainage basin of the Mladotice Lake were reconstructed from air images. Figure 7 shows about $1 \mathrm{~km}^{2}$ of farmland northeast of Žihle in the drainage basin of the Mladotice Lake. No changes are visible in the field patterns between 1938 and 1952. Collective farming had the greatest impact between 1952 and 1975, when fields were made much larger. A further increase in the size of some fields is visible in 1987. The photos taken in 1998 show that the size of the fields was reduced again after the political change in the Czechia (Czechoslovakia) in 1989. Bigger fields facilitate soil erosion due to longer slopes and increased surface runoff (see conclusions). Some quantitative data about land use changes were published also in Schulte et al. (2006).

\subsection{Changes in flood discharge}

To clarify whether the system changes are due to natural or anthropogenic causes, we analysed the time series of discharges at the Strela gauge at Plasy $\left(775 \mathrm{~km}^{2}\right)$, recorded since 1941 . Figure 8 shows maximum daily discharges. 
The flood events data of more than $20 \mathrm{~m}^{3} / \mathrm{s}$ (one-year flood) give a frequency of 34 floods within 30 years (1941-1970, with several events in one year ) which decreases to a frequency of 25 events in following 30 years (1978-2007). Furthermore, the analyses show that the magnitude of the peak discharge has been decreasing as well, especially over the past 30 years. The average longterm discharge (1941-2007) at the Střela gauge station at Plasy is $2.896 \mathrm{~m}^{3} / \mathrm{s}$. The peak discharge from 9 May 1978, i.e. $145 \mathrm{~m}^{3} / \mathrm{s}$, was classified as a thirtyyear flood.

\subsection{Stratigraphy of lake sediments}

The lake sediments of reference core ML 18/03 (Fig. 9) are largely muddy silts. The particle-size distribution in Figure 10 shows two noteworthy features: (1) Sand is found only in the lower sediment sequences. This is also the case in the other sediment cores and suggests that the sand was brought in by the Mladotický stream. During the early decades there may have been some additional sediment input from the mass failure area, which was without any vegetation during the first few years. (2) The particle-size median shows a distinct change in sedimentation at about $190 \mathrm{~cm}$. Below this depth the sediment is coarser and the range fluctuates fairly widely; above it, the median remains constant at about $4 \mu \mathrm{m}$ (Fig. 10).

Sediment cores ML 14/03 and ML 16/03 show clear evidence of the system change. According to macroscopic and stratigraphic analyses of these cores the system change occurred at different depths owing to the different thickness of sediments.
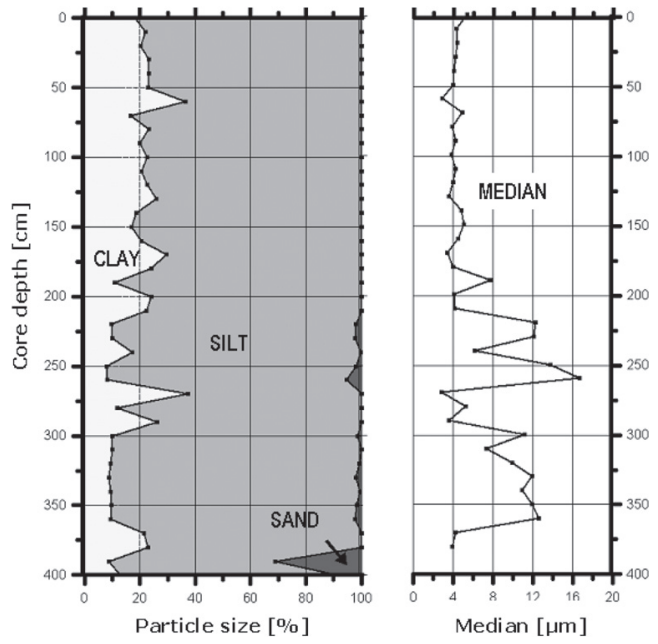

Fig. 10 - Particle size distribution of sediment core ML 18/03 (core depth 0-400 cm)

Qualitative X-ray diffractometry revealed the principal mineral components of the sediments to be quartz, plagioclase, potash feldspar, muscovite, kaolinite and chlorite. Some samples in this core showed very low concentrations of pyrite, siderite and haematite. Calcite was found only in near-surface deposits.

\subsection{Analyses of isotopes and sedimentation $r$ ates}

The absolute chronology of the sediments is also based on available ${ }^{137} \mathrm{Cs}$, ${ }^{241} \mathrm{Am}$ and ${ }^{210} \mathrm{~Pb}$ measurements (Fig. 11). The radiation of ${ }^{137} \mathrm{Cs}$ and ${ }^{241} \mathrm{Am}$ maxi- 
mum at a core depth of $100 \mathrm{~cm}$ is attributed to the 1963 maximum of bomb fallout which started in 1954. Americium clearly demonstrates bomb fallout because there was no emission of americium during the Chernobyl disaster. The peak at $40 \mathrm{~cm}$ core depth is assigned to the Chernobyl fallout in 1986 .

Thin sections give an additional chronology, in some cases with the accuracy of one year. The new sediment data on geochemistry, isotopes, and thin sections especially of core ML 18/03 and partly of core ML 14/03 yield the following interpretation (Fig. 12):

The 1872 landslide impounded the lake and sedimentation began. Thin section analyses show that clastic sediments were deposited in annual layers above the base. In some cases the boundaries between the layers are blurred, resulting in erroneous ages for the lower part of the core. It was possible to count the layers up to 1883 with an error of \pm 2 years. The average sedimentation rate was $1.8 \mathrm{~cm} / \mathrm{a}$ (Albrecht 2007).

This was followed by a $50 \mathrm{~cm}$ thick, homogeneous sequence of unbedded sediment. We interpret this sediment as having been deposited during an event or a phase of events prior to 1890 (average sedimentation rate $9.1 \mathrm{~cm} / \mathrm{a}$ ). The material comes either from the still unvegetated mass failure area at the southern end of the lake or from flood input by the Mladotický stream. Analyses of the other long cores will yield detailed information about the dumping direction.

Up to $190 \mathrm{~cm}$ core depth, thick unbedded sequences alternate with annually bedded sediments. A layer count dated this depth to 1920. Partial blurring of the boundaries between the layers results in a possible error of \pm 5 years. Owing to the alternation between event-dependent high sediment inputs and annual sediment layers, there are substantial variations in sedimentation rates between 6.7 and $1.8 \mathrm{~cm} / \mathrm{a}$.

Above $160 \mathrm{~cm}$ core depth there is a clearly bedded diatom mud that can be dated relatively accurately by various sediment analyses. The start of bomb fallout in 1954 provides a time marker $(120 \mathrm{~cm}$ core depth). The sedimentation rate between 1920 and 1954 was calculated at $2.1 \mathrm{~cm} / \mathrm{a}$. Maximum fallout at $100 \mathrm{~cm}$ core depth occurred in 1963 (sedimentation rate $2.2 \mathrm{~cm} / \mathrm{a}$ ). The next time marker is the flood of 1978, shown by a distinct event layer and a change in diatom composition. The sedimentation rate from 1963 to 1978 was calculated at $2.7 \mathrm{~cm} / \mathrm{a}$. Until the fallout from Chernobyl in 1986 the sedimentation rate fell only slightly to $2.5 \mathrm{~cm} / \mathrm{a}$ (Fig. 12). The rate is $2.4 \mathrm{~cm} /$ a between 1986 and the sediment surface (2003).

\section{Conclusions}

Data obtained from various sediment analyses yield a high temporal resolution of the sediment stratigraphy. In 1920 the sedimentation rate was $2.1 \mathrm{~cm} / \mathrm{a}$, then came a slight rise, reaching $2.7 \mathrm{~cm} / \mathrm{a}$ after 1963 . Because this increase cannot be attributed to greater frequency or amplitude of large floods we conclude that the switch to collective agriculture was responsible for the increase in sediment entering the lake. If we disregard the extraordinary event layers when calculating sedimentation rates, greater importance then attaches to the change in land use. The differences in sedimentation rates are smaller but still remain (Fig. 12). 
All units in Bqikg

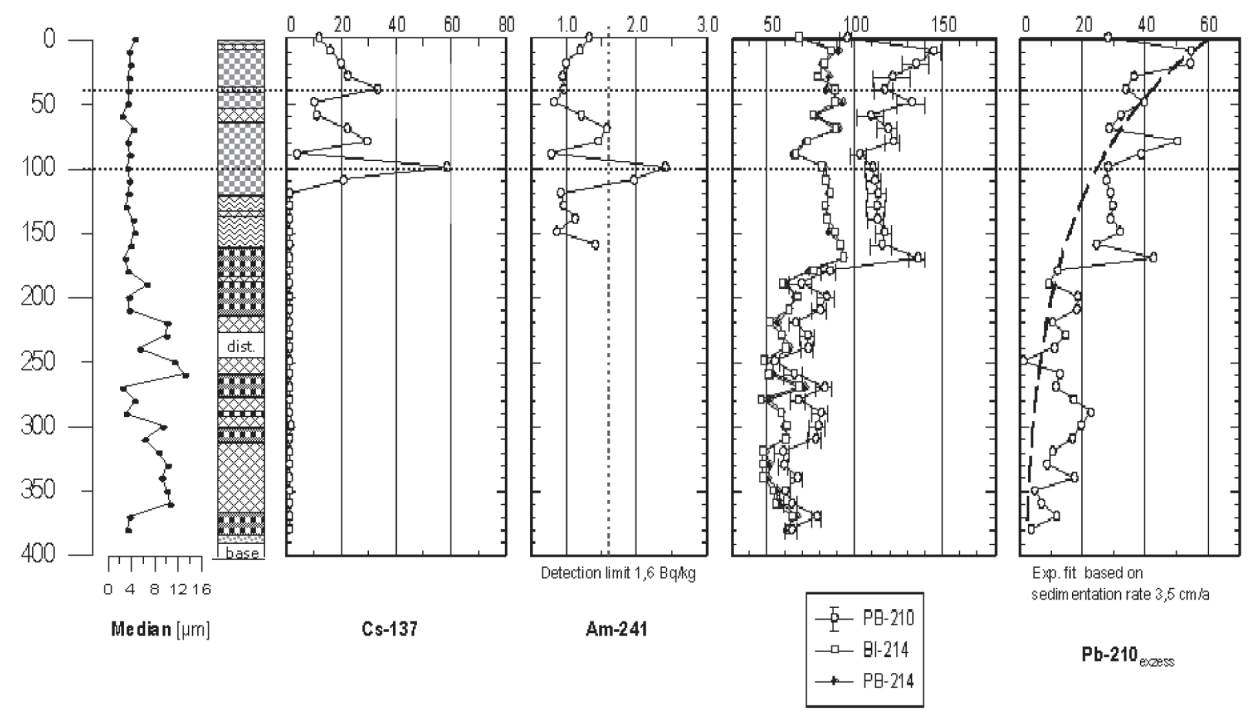

Fig. 11 - Isotope contents in reference core ML $18 / 03\left({ }^{137} \mathrm{Cs},{ }^{241} \mathrm{Am},{ }^{210} \mathrm{~Pb}\right)$

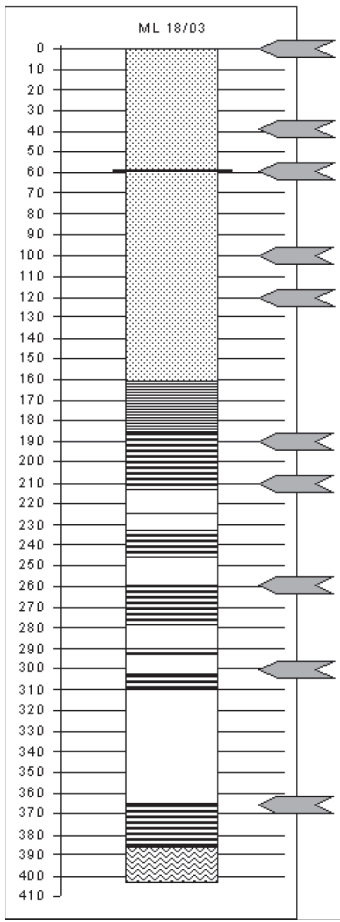

2003 sediment surface

1986 Tschemobyl fallout

1978 bigger flood event

1963 max. bomb fallout

1954 start bomb fallout

Sedimentation rate [cm/a]

(leave out events)

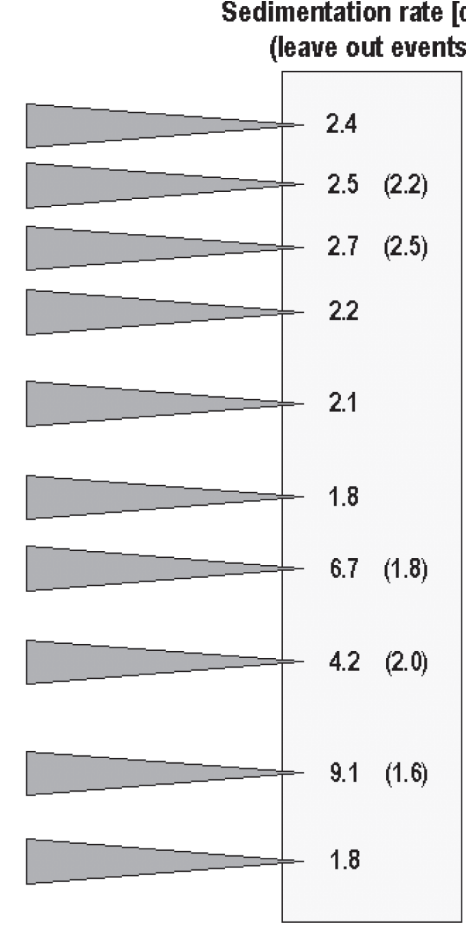

Fig. 12 - Results of thin section analyses, temporal resolution and calculated sedimentation rates

$1920+1-5$ counted layers $1907+1-5$ counted lavers

$1900+1-2$ counted layers

$1890+1-1$ counted layers

$1883+1-2$ counted layers

1872 mass movement 
Collectivization led to larger units of farmland. According to Janský (1976, 1977) and Janský and Urbanová (1994) the enlargement process was most active during the 1960s and 1970s and was accompanied by the removal of field terraces. In consequence slopes became steeper and the fine colluvial material that had collected above the terraces over decades or centuries was easily remobilized. From then on, the bigger fields were worked by larger and heavier agricultural machinery, thus increasing soil compaction and erodibility. Greater slope length, steeper slope angle and modified farming practices intensify average soil erosion according to the Universal Soil Loss Equation (Wischmeier, Smith 1978). A substantial increase in sediment input and deposition might be expected, but did not occur to the anticipated extent.

These results may be interpreted in two ways: (1) The amount of soil erosion from the parts of the drainage basin used for agriculture corresponds to the sediment increase in the lake and the additional transport through the lake. (2) Soil erosion has increased much more than is indicated by the lake's sedimentation rates, because a proportion of the sediments was deposited in colluvial, alluvial and lake inflow areas. If the latter is the case, such sinks are likely to provide relevant information.

In 31 years, $37,471 \mathrm{~m}^{3}$ of sediment accumulated in the lake basin (Table 1). This represents a sedimentary deposit of $1,209 \mathrm{~m}^{3}$ per year. If we consider the current volume of the lake basin $-103,910 \mathrm{~m}^{3}$, this means that, under the existing dynamics of sedimentation, the lake would be entirely filled in after 86 years! The sedimentation of the lake is occurring primarily around its largest tributary. At the present time, the area of maximum depth is not so intensively impacted by the sedimentation process as is the area near tributaries. However, this situation shall change in the final phase of the basin's sedimentation, when it can be expected that the area of the tributaries will move significantly closer to the area of maximum depth.

In addition to the speed of sedimentation, the lakes drainage could also play a significant role in its future development. Over time, the drainage will cut deeper and deeper into the lake's dam. During extreme floods, the drainage channel could be markedly deepened. This would mean the lowering of the water level and the quicker disappearance of the lake. Processes of sedimentation in the Mladotice Lake basin could be slowed by implementing thorough anti-erosion, soil-protection measures throughout the entire catchment area of the lake along with changes in land use (with preference given to permanent grasslands and decreases in arable land), as well as by making adjustments to the drainage stream at the lake's dam.

\section{References:}

ALBRECHT, M. (2007): Die Sedimente des Mladoticer Sees in W-Tschechien als Archiv der vor- bis nachkommunistischen Umweltveränderungen. PhD Thesis, Freie Universität Berlin, Germany.

ANDRES, W. (1998): Terrestrische Sedimente als Zeugen natürlicher und anthropogener Umweltveränderungen seit der letzten Eiszeit. In: Dikau, R., Heinritz, G., Wiessner, R. (Hrsg.): Global Change - Konsequenzen für die Umwelt. Deutscher Geographentag Bonn, 3, Stuttgart, pp. 118-133. 
BARSCH, D., MÄUSBACHER, R., SCHUKRAFT, G., SCHULTE, A. (1993): Die Änderungen des Naturraumpotentials im Jungneolithikum des nördlichen Kraichgaus dokumentiert in fluvialen Sedimenten. Zeitschr. für Geomorph., 93, Suppl., pp. 175-187.

BIČÍK, I., KABRDA, J. (2007): Land use changes in Czech border regions (1845-2000). Acta Universitatis Carolinae - Geographica, XLII, No. 1-2, pp. 23-52.

BIČÍK, I., JELEČEK, L. (2009): Land use and landscape changes in Czechia in transformational period 1990-2007. Geografie, 114, No. 4, Praha, pp. 26-52.

BORK, H. R., BORK, H., DALCHOW, C., FAUST, B., PIORR, H. P., SCHATZ, T. (1998): Landschaftsentwicklung in Mitteleuropa. Wirkungen des Menschen auf Landschaften. Justus Perthes Verlag Gotha GmbH, Gotha, 328 pp.

BRÁZDIL, R., DOBROVOLNÝ, P., ELLEDER, L., KAKOS, V., KOTYZA, O., KVĚTOŇ, V., MACKOVÁ, J., MÜLLER, M., ŠTEKL, J., TOLASZ, R., VALÁŠEK, H. (2005): Historické a současné povodně v České republice. Masarykova univerzita, Český hydrometeorologický ústav, Brno, Praha, 370 pp.

ČESÁK, J., ŠOBR, M. (2005): Metody batymetrického mapování českých jezer. Geografie, 110 , No. 3, pp. 141-151.

ČUŘÍK, J. (2009): Hydrologický režim Mladotického jezera. Master thesis, PřF UK, Praha.

FAVIS-MORTLOCK, D., BOARDMAN, J., BELL, M. (1997): Modelling long-term anthropogenic erosion of a loess cover: South Downs, UK. The Holocene 7, No. 1, pp. 79-89.

FERNANDEZ, P., VILANOVA, R. M., GRIMALT, J. O. (1999): Sediment fluxes of polycyclic aromatic hydrocarbons in European high altitude mountain lakes; Environ Sci Technol 33, pp. 3716-3722.

Geologická mapa ČR, listy 12-13 Jesenice a 12-31 Plasy, 1:50 000, Český geologický ústav, Praha 1996.

GEYH, M. A. (2005): Handbuch der physikalischen und chemischen Altersbestimmung. Wissenschaftliche Buchgesellschaft, Darmstadt, $211 \mathrm{pp}$.

HEILAND, J. (1998): Translational block-type slope movements - mechanism and examples. Acta Montana IRSM. Series AB, No. 6, pp. 81-137.

JANSKÝ, B. (1976): Mladotické hrazené jezero - geomorfologie sesuvných území. Acta Universitatis Carolinae - Geographica, XI, No. 1, pp. 3-18.

JANSKÝ, B. (1977): Mladotické hrazené jezero - morfografické a hydrografické poměry. Acta Universitatis Carolinae - Geographica, XII, No. 1, pp. 31-46.

JANSKÝ, B., URBANOVÁ, H. (1994): Mladotice Lake (Czech Republic) - siltation dynamics in the lake basin. Acta Universitatis Carolinae - Geographica, XXIX, No. 2, pp. 95-109.

JANSKÝ, B. (2003): Dynamika zanášení Mladotického jezera. In: Janský, B., Šobr, M. a kol.: Jezera České republiky. Katedra fyzické geografie a geoekologie, PřFUK, Praha, pp. 65-70.

JUNGE, F. W., JENDRYSCHIK, K., MORGENSTERN, P., TREUTLER, H.-C., ZERLING, L. (2005): Sediment cores from river dams as flood archives. Studia Quaternaria, 21, pp. 187-195.

KADEREIT, A., LANG, A., HÖNSCHEIDT, S., MÜTH, J., WAGNER, G. A. (2002): IR-OSLdated colluvial archives as evidence for the Holocene landscape history. Case studies from SW Germany. Z. Geomorph. N.F. Suppl., 128: pp. 191-207.

KADLEC, J., GRYGAR, T., SVĚTLÍK, I., ETTLER, V., MIHALJEVIČ, M., DIEHL, J. F., BESKE-DIEHL, S., SVITAVSKÁ-SVOBODOVÁ, H. (2009): Morava River floodplain development during the last millennium, Strážnické Pomoraví, Czech Republic. The Holocene, 19, pp. 499-509.

KALIS, A. J., MERKT, J., WUNDERLICH, J. (2003): Environmental changes during the Holocene climatic optimum in central Europe - human impact and natural causes. Quaternary Science Reviews, 22, pp. 33-79.

KOŘISTKA, K. (1872):Všeobecný nástin meteorologických a vodopisných poměrů, jakož i škod na vzdělané půdě a komunikacích za povodně dne 25. a 26. května 1872. In: Zprávy kanceláře pro statistiku polního a lesního hospodářství v Království Českém. Book 1, Praha, pp. 3-16.

LANG, A. (2003): Phases of soil erosion - derived colluviation in the loess hills of South Germany. Catena, 51, pp. 209-221. 
MURI, G., WAKEHAM, S. G., FAGANELI, J. (2003): Polycyclic aromatic hydrocarbons and black carbon in sediments of a remote alpine lake (Lake Planina, Northwest Slovenia); Environ Toxicol Chem, 22, pp. 1009-1016.

SCHULTE, A., HECKMANN, T. (2002): Human influence on Holocene environmental change in the Hegau region, SW Germany. Z. Geomorph. N.F. Suppl., 128, pp. 67-79.

SCHULTE, A., ALBRECHT, M., DAUT, G., WALLNER, J., JANSKÝ, B., VAN GELDERN, R. (2006): Analyses and assessment of the sedimentary record of Lake Mladotice (western Czech Republic) in relation to flood events and pre- to postcommunist change in land use. Zeitschrift für Geomorphologie, Suppl., 142, pp. 229-243.

SKREJŠOVSKÝ, F. (1872): Zhoubná povodeň v Čechách dne 25. a 26. května roku 1872, Praha, 142 pp.

ŠTEKL, J., BRÁZDIL, R., KAKOS, V., JEŽ, J., TOLASZ, R., SOKOL, Z. (2001): Extrémní denní srážky na území České republiky v období 1879-2000 a jejich synoptické př́ičiny. Národní klimatický program ČR, 31, 128 pp.

VÖLKEL, J., ed. (2005): Colluvial Sediments, Flood Loams and Peat Bogs. Zeitschrift für Geomorphologie N.F. Suppl., 139.

WISCHMEIER, W. H., SMITH, D. D. (1978): Predicting rainfall erosion losses: a guide to conservation planning. U.S. Gov. Print. Off., Washington, 58 pp.

ZOLITSCHKA, B., BEHRE, K. E., SCHNEIDER, J. (2003): Human and climatic impact on the environment as derived from colluvial, fluvial and lacustrine archives - examples from the Bronze Age to the Migration period, Germany. Quaternary Science Reviews, 22, pp. 81-100.

\section{Shrnutí}

\section{MLADOTICKÉ JEZERO, ZÁPADNÍ ČESKO: JEDINEČNÁ GENEZE A VYYOJ JEZERNÍ PÁNVE}

Na konci května 1872 byla rozsáhlá oblast jihozápadních a západních Čech postižena mohutnou průtrží mračen, která podle historických zpráv trvala od poledne 25 . května do rána příštího dne. Dne 25. 5. 1872 zaznamenala srážková stanice Plzeň dvě bouře, při nichž bylo naměřeno celkem $40 \mathrm{~mm}$ srážek. Daleko vyšší srážky však spadly severně od Plzně na Kralovicku, kde nebyla v té době činná žádná srážkoměrná stanice. Podrobný popis tehdejší meteorologické situace však podal významný kartograf Karel Kořistka: „V Mladoticích u Kralovic pozorováno, kterak venku stojící prázdná nádoba za hodinu na 9 palců (tj. $237 \mathrm{~mm}$ ) až po svůj okraj vodou se naplnila a za dalšího deště přetékala..." Hodinový úhrn srážek $237 \mathrm{~mm}$ byl dlouho považován za nereálný, teprve měřením doložená průtrž mračen na jižním Slovensku z 12. 6. 1957, kdy ve stanici Salka u Štúrova spadlo 225,5 mm srážek za 65 minut, potvrdila reálnost tohoto údaje. Tyto extrémní srážky způsobily mimořádně ničivou povodeň, která katastroficky postihla povodí Střely, Blšanky a většinu povodí Berounky pod Plzní. Dne 26. května ve 14 hodin byl naměřen průtok Vltavy v Praze $3300 \mathrm{~m}^{3} / \mathrm{s}$, což představuje pátou největši povodeň za dobu instrumentálního sledování od roku 1825.

Po mimořádně intenzivních srážkách došlo v povodí Mladotického potoka (levý přítok řeky Střely) ke dvěma přírodním katastrofickým událostem. Již v noci z 27. na 28. května se sesuly ze západního úbočí Potvorovského vrchu do údolí Mladotického potoka masy arkóz a zatarasily ho mohutnou hrází. Vzniklo jezero, které je jediným zástupcem tohoto genetického typu na území Českého masivu. O den později se protrhla hráz Mladotického rybníka, který se nacházel na jižním okraji obce Mladotice a s plochou kolem 92 ha byl tehdy největším rybníkem západních Čech.

Sto let po vzniku jezera provedl autor článku první geomorfologický výzkum sesuvných území včetně geodetického vyměření půdorysu a vyhotovení mapy hloubek Mladotického jezera. Studium archivních materiálů a terénní výzkum potvrdily, že přičin sesuvu v roce 1872 bylo několik:

Údolí Mladotického potoka je pravděpodobně predisponováno tektonicky. Vlivem hloubkové eroze se potok stále více zařezával do souvrství karbonských arkóz, pískovců a slepenců. Po proříznutí komplexu těchto pískovcových hornin se vodní tok dostal až do poloh měkkých jílovcových sedimentů. Ty nasákly vodou a u paty svahu vznikly pravděpodobně 
podružné smykové plochy. Voda se však k podložním jílovitým polohám dostávala též četnými tahovými trhlinami v horní části svahu. Vzhledem $\mathrm{k}$ tomu, že skalní masív byl již narušen, posouvaly se celé bloky hornin směrem do údolí. Posunem spodní části svahu byly vytvořeny podmínky pro posun dalších, stále vyšších bloků. Pohyb plouživého charakteru proběhl zřejmě v celé oblasti vymezeného sesuvného území (sesuvy I, II, III), pouze v oblasti sesuvu I došlo k dalšímu pohybu v roce 1872, který měl znaky skalního řícení.

Druhým faktorem, který rovněž přispěl k porušení stability západního svahu Potvorovského vrchu, byl vliv antropogenní. Je zde několik bývalých lomů, v nichž se po staletí těžily pískovcové kvádry na výrobu mlýnských kamenů i na významné stavby v okolí. O těžbě v této lokalitě existuje přitom celá řada historických důkazů. Byly např. použity již na stavbu románského kostela Sv. Mikuláše v Potvorově (kolem roku 1240), v 18. století se kvádry vozily též na dostavbu konventu do Plas. Za dlouhou řadu let tedy i těžba přispěla ke snížení stability svahu. Kromě toho bylo při těžbě rozrušeno nadloží a tím byl umožněn snadnější přístup srážkové vody $\mathrm{k}$ podložním polohám jílovcových hornin.

Třetím činitelem, který též určitou měrou přispěl ke snížení stability svahu, byl výkop zářezu pro železniční trat', která byla v roce 1872 ve výstavbě a ještě téhož roku měla být otevřena. Zářez protnul západní úbočí Potvorovského vrchu v délce 150-200 m. Vzhledem $\mathrm{k}$ tomu, že po katastrofálním sesuvu nedošlo k podstatnému porušení tohoto zářezu, nýbrž pouze k posunu asi o 75-80 m směrem po svahu, můžeme se domnívat, že stavba trati a s ní spojené prokopání západního svahu nebyly rozhodující příčinou sesuvu.

Posledním časově nejmladším faktorem pro vznik svahových pohybů byly intenzivní deštové srážky na konci května 1872. Svah byl již dostatečně rozrušen četnými trhlinami, puklinami, lomy i zářezem trati. Do takto narušeného nadloží se snadno dostávaly mohutné vodní přívaly. Voda se však dobře vsakovala i do samotných hrubozrnných porézních arkóz, pískovců a slepenců. Takto prosakující vody byly pravděpodobně zadrženy nepropustnými jemnozrnnými pískovci a lupky povahy silně jílovité, slídnaté a tence deskovité. Tím se podstatně zvýšila váha nadloží a změnily se i ostatní fyzikální vlastnosti komplexu pískovcových hornin (pevnost, napjatost hornin apod.). Po nasáknutí vodou změkl jílovitý tmel a též červenavé nebo světle šedé lupky v podloží se rozmočily. Došlo ke zmenšení tření a vzhledem $\mathrm{k}$ tomu, že úklon vrstev je asi 10-14 stupňů k západu (tedy směrem po svahu), začaly se masy nadloží sunout do údolí potoka. Ve srovnání s posouváním plouživým, které asi postihlo mnohem dříve celé sesuvné území a o kterém už byla zmínka, byl tento pohyb mnohem rychlejší a proběhl ve dvou dnech 27 . a 28 . května 1872 . Sesuv přehradil údolí v délce 300 metrů.

Kromě geneze Mladotického jezera se autoři článku zabývají faktory, které ovlivnily další vývoj jezerní pánve. $\mathrm{V}$ této souvislosti by měly být zodpovězeny následující otázky:

Jak hluboké bylo jezero bezprostředně po vzniku? $\mathrm{K}$ jakým změnám ve využití ploch („land use“) došlo v povodí jezera od roku 1872 do současnosti? Do jaké míry se na intenzitě zanášení podílely mimořádné povodňové situace a do jaké míry $\mathrm{k}$ nim přsispěly změny $\mathrm{v}$ „land use“ v povodí?

První metodou k dosažení výše stanovených cílů jsou batymetrická měření. První mapa hloubek byla vytvořena v roce 1972, hloubková měření byla byla poté opakována v letech 1990, 1999 a 2003. Na základě porovnání výsledků z let 1972 a 2003 bylo zjištěno, že objem jezerní pánve se snížil o $37471 \mathrm{~m}^{3}$, tj. o $26,5 \%$, přičemž plocha jezera poklesla o $19 \%$.

Pomocí analýzy leteckých snímků z let 1938, 1952, 1975, 1987 and 1998 byl analyzován vývoj „land use” na experimentální ploše v povodí jezera o rozloze kolem 1 km². Bylo prokázáno, že největší změny ve velikosti obhospodařovaných ploch nastaly od počátku kolektivizace zemědělství v roce 1952 do roku 1975. Zvětšování pozemků pokračovalo až do roku 1987. Politické změny v roce 1989 spojené s navracením zemědělské půdy původním vlastníkům odstartovaly proces opětovného zmenšování plochy pozemků.

Byla vyhodnocena řada průměrných denních průtoků v nejbližší hydrologické stanici Plasy (řeka Střela) za období 1941-2007. Vedle analýzy četnosti jednoletých povodňových průtoků bylo zjištěno, že 9 . května 1978 se na řece Střele vyskytla 40letá velká voda, která dosáhla ještě větší extremity v povodí Mladotického potoka.

Pomocí několika metod popsaných v textu práce byla určena absolutní chronologie sedimentů. Velmi cenné výsledky přineslo zejména datování pomocí obsahu radioaktivních izotopů ${ }^{137} \mathrm{Cs}$, ${ }^{241} \mathrm{Am}$ and ${ }^{210} \mathrm{~Pb}$. To umožnilo identifikaci počátku pokusů s jadernými zbraněmi v roce 1954, stanovení vrcholu jaderných výbuchů v roce 1963, odpovídající hloubce kolem 
$100 \mathrm{~cm}$ pod povrchen současného dna jezera, a zachycení výbuchu Černobylské jaderné elektrárny v roce 1986, což odpovídá hloubce sedimentárního pokryvu $40 \mathrm{~cm}$. Na základě stratigrafického vyhodnocení lze určit rychost sedimentace v různých fázích vývoje jezerní pánve. Můžeme konstatovat, že největší rychost zanášení (kolem $9 \mathrm{~cm} / \mathrm{rok}$ ) byla zjištěna v prvním období po vzniku jezera do roku 1890, kdy materiál hráze ani břehové partie nebyly dosud zpevněny vegetací. Poté rychlost sedimentace poklesla na $4,2 \mathrm{~cm} /$ rok do konce 19 . století a opět se zvýšila na $6,7 \mathrm{~cm} /$ rok do roku 1907 . Toto zvýšení mohlo být způsobeno nějakou mimořádnou hydrologickou událostí. Následuje snížení dynamiky zanášení na hodnoty od 1,8 do $2,1 \mathrm{~cm} /$ rok a opětovné zvýšení rychosti sedimentace v období kolektivizace zemědělství na $2,7 \mathrm{~cm}$ ročně. $V$ posledních dvaceti letech se pak dynamika sedimentace mírně snížila.

Povodňové události ovlivnily proces sedimentace výrazně, a to jak z hlediska zrnitosti tak mocnosti nánosů. Změny v „land use” v povodí ovlivnily rychlost sedimentace menší měrou, než bylo očekáváno. Jezero mělo po vzniku maximální hloubku kolem 11 metrů.

Obr. 1 - Lokalizace povodí Mladotického jezera a výzkumné oblasti v západních Čechách.

Obr. 2 - Mapa 3. vojenského mapování Rakouské monarchie z roku 1890. Na mapě je znázorněno nově vzniklé Mladotické jezero a bývalý Mladotický rybník, který se nacházel na jižním okraji obce Mladotice.

Obr. 3 - Přehledná mapa sesuvných území na západním úbočí Potvorovského vrchu. I - sesuvné území z roku 1972, II, III - starší sesuvná území.

Obr. 4 -Zahrazené údolí bezprostředně po sesuvu v květnu 1872, v pozadí vznikající jezero. Otisk z Geografie (Sborníku ČSZ) 28 z roku 1912. Foto C. Purkyně.

Obr. 5 -Násep železniční trati po sesuvu v květnu 1872. Otisk z Geografie (Sborníku ČSZ) 28 z roku 1912. Foto C. Purkyně.

Obr. 6 - Batymetrické mapy Mladotického jezera z měření hloubek v letech 1972 a 2003.

Obr. 7 - Letecké snímky pole o rozloze kolem $1 \mathrm{~km}^{2}$ severovýchodně od města Žihle v povodí Mladotického jezera. Největší změny ve využití ploch nastaly od počátku kolektivizace zemědělství (1952) do roku 1975. Foto: Vojenský topografický ústav Dobruška.

Obr. 8 - Maximální denní průtoky v hydrologické stanici Plasy (řeka Střela) v období 1942-2007. Osa x - roky. Zdroj: ČHMU, Čuřík 2009.

Obr. 9 - Mapa Mladotického jezera s lokalizací mělkých a hlubokých vrtů. Vrt ML 18/03 se nachází blízko výtoku v oblasti největších hloubek jezera.

Obr. 10 - Zastoupení jednotlivých zrnitostních frakcí v sedimentu vrtu ML 18/03 (hloubka vrtu $0-400 \mathrm{~cm}$ ).

Obr. 11 - Obsah radioaktivních izotopů ${ }^{137} \mathrm{Cs},{ }^{241} \mathrm{Am}$ a ${ }^{210} \mathrm{~Pb}$ v referenčním vrtu ML 18/03.

Obr. 12 - Výsledky detailní sekční analýzy, časového vývoje a vypočtených rychlostí sedimentace.

B. Janský and J. Česák are affiliated with Charles University in Prague, Faculty of Science, Department of Physical Geography and Geoecology, Albertov 6, 12843 Prague 2, Czechia; e-mail: jansky.b@seznam.cz; julekc@natur.cuni.cz.A. Schulte is affiliated with Institute of Geographical Sciences, Department of Earth Sciences, Freie Universität Berlin, Malteserstr. 74-100, D-12249 Berlin, Germany; e-mail: achim.schulte@fu-berlin.de. V. Rios Escobar is affiliated with University of Medelin, Columbia; e-mail: vriosescobar@gmail.com.

Initial submission 15 December 2009; final acceptance 5 May 2010.

\section{Citační vzor:}

JANSKÝ, B., SCHULTE, A., ČESÁK, J., RIOS ESCOBAR, V. (2010): The Mladotice Lake, Western Czechia: The unique genesis and evolution of the lake basin. Geografie, 115, č. 3, s. 247-265. 